\title{
Sludge in a giant left atrium
}

\author{
Yoshito Kadoya, Michiyo Yamano, Satoaki Matoba
}

Department of Cardiovascular Medicine, Graduate School of Medical Science, Kyoto Prefectural University of Medicine, Kyoto, Japan

\section{Correspondence to} Dr Yoshito Kadoya, m03020kdy@gmail.com

Accepted 3 October 2016
CrossMark

\footnotetext{
To cite: Kadoya $Y$, Yamano M, Matoba S. BMJ Case Rep Published online: [please include Day Month Year] doi:10.1136/bcr-2016217660
}

\section{DESCRIPTION}

A man aged 78 years who had been diagnosed with end-stage hypertrophic cardiomyopathy presented with dyspnoea. He was admitted to our hospital with a diagnosis of acutely exacerbated chronic heart failure. The patient had previously undergone bioprosthetic mitral valve replacement for nonrheumatic mitral regurgitation and pacemaker implantation for atrial fibrillation, with a slow ventricular response. He had received anticoagulation therapy (warfarin). Chest radiography revealed cardiomegaly with a markedly enlarged left atrial appendage (figure 1A). CT revealed massive left atrial enlargement (maximum diameter, $20.6 \mathrm{~cm}$ ) and right-sided pleural effusion (figure 1B). A transthoracic echocardiogram showed a severely enlarged left atrium and mild degree of transvalvular regurgitation. The bioprosthetic mitral valve stenosis was insignificant; the mean pressure gradient of the mitral valve was $3.4 \mathrm{~mm} \mathrm{Hg}$ on echocardiography, and the mean pressure difference between the pulmonary capillary wedge pressure and left ventricular pressure was $3.7 \mathrm{~mm} \mathrm{Hg}$ on cardiac catheterisation. Although a relevant structural abnormality of the mitral valve prosthesis was not observed on transoesophageal echocardiography, a severely enlarged left atrium containing significant thrombus-free sludge could be seen (figure 2 and video 1). Sludge is a dynamic, gelatinous, precipitous echodensity without a discrete mass and is considered a more advanced stage along the spectrum of thrombus formation compared with spontaneous echo contrast. ${ }^{1}{ }^{2}$ Comparable mortality and thromboembolic risk

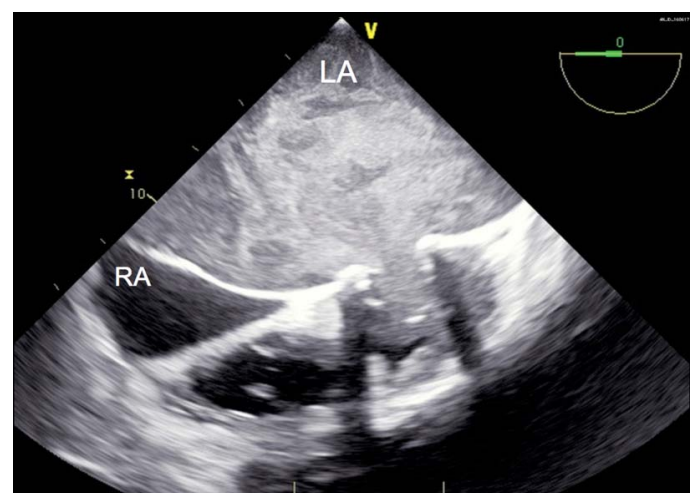

Figure 2 Enlarged left atrium with thrombus-free sludge on TEE. TEE, transoesophageal echocardiogram; $L A$, left atrium; $R A$, right atrium.

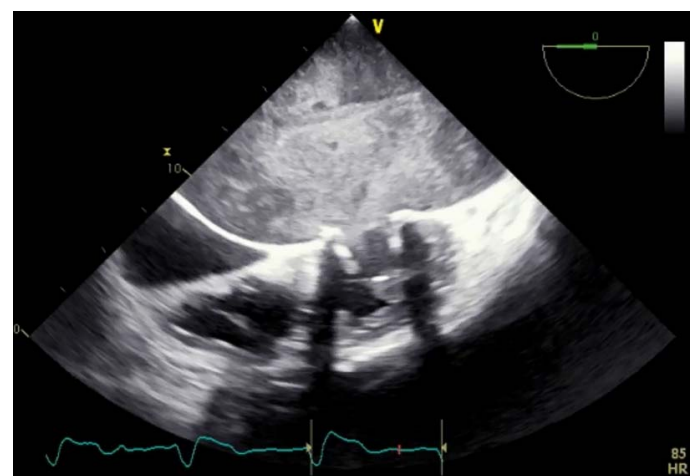

Video 1 Enlarged left atrium with thrombus-free sludge on TEE. TEE, transoesophageal echocardiogram.

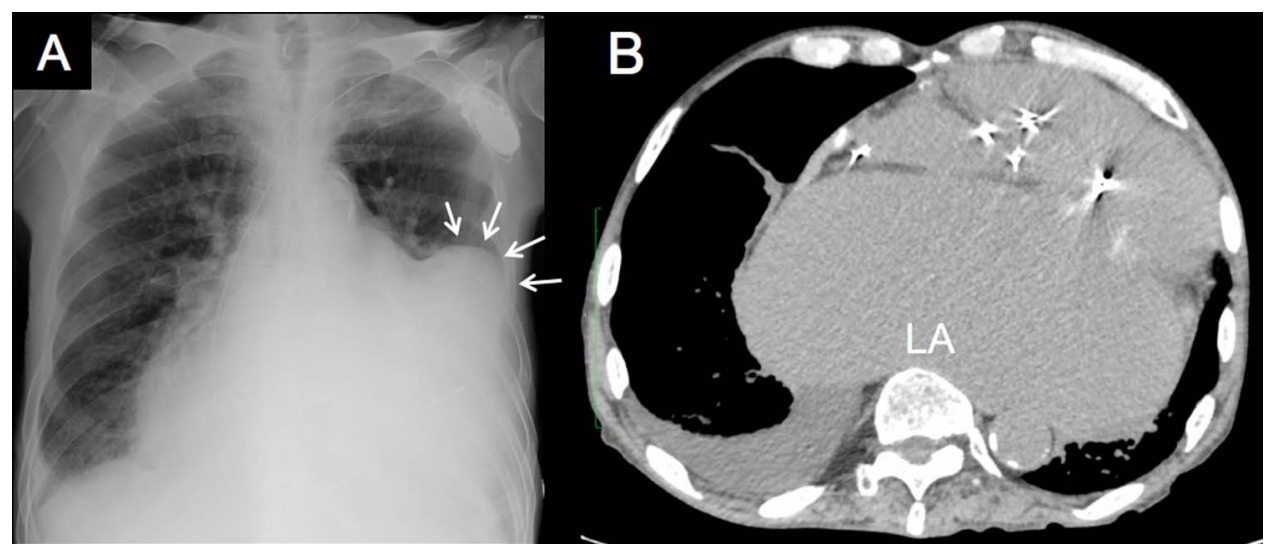

Figure 1 (A) Cardiomegaly with enlarged left atrial appendage (arrows). (B) Left atrial enlargement and right-sided pleural effusion on CT scan. LA, left atrium. 
have been reported in patients with atrial fibrillation with sludge and those with thrombi. ${ }^{3}$ Strict anticoagulation therapy should be administered to patients with sludge. The patient quickly recovered from a decompensated state and did not develop thrombotic complications.

\section{Learning points}

- Sludge is a more advanced stage along the spectrum of thrombus formation compared with spontaneous echo contrast.

- Strict anticoagulation therapy should be administered to patients with sludge.
Contributors YK is responsible for clinical management of the case, manuscript redaction and correction. MY is responsible for manuscript redaction and correction. SM is responsible for manuscript redaction and correction. All authors read and approved the final manuscript.

Competing interests None declared.

\section{Patient consent Obtained.}

Provenance and peer review Not commissioned; externally peer reviewed.

\section{REFERENCES}

1 Hajjiri M, Bernstein S, Saric M, et al. Atrial fibrillation ablation in patients with known sludge in the left atrial appendage. J Interv Card Electrophysiol 2014;40:147-51.

2 Wazni OM, Tsao HM, Chen SA, et al. Cardiovascular imaging in the management of atrial fibrillation. J Am Coll Cardiol 2006;48:2077-84.

3 Lowe BS, Kusunose $\mathrm{K}$, Motoki $\mathrm{H}$, et al. Prognostic significance of left atrial appendage 'sludge' in patients with atrial fibrillation: a new transesophageal echocardiographic thromboembolic risk factor. J Am Soc Echocardiogr 2014;27:1176-83.

Copyright 2016 BMJ Publishing Group. All rights reserved. For permission to reuse any of this content visit http://group.bmj.com/group/rights-licensing/permissions.

BMJ Case Report Fellows may re-use this article for personal use and teaching without any further permission.

Become a Fellow of BMJ Case Reports today and you can:

- Submit as many cases as you like

- Enjoy fast sympathetic peer review and rapid publication of accepted articles

- Access all the published articles

- Re-use any of the published material for personal use and teaching without further permission

For information on Institutional Fellowships contact consortiasales@bmjgroup.com

Visit casereports.bmj.com for more articles like this and to become a Fellow 